\title{
Analysis of Collaboration between Enterprises and Public Research Organisations \\ on Co-Financed Research-and-Development Projects
}

Tina Žitko

University of Primorska, Slovenia

tinazitko@gmail.com

Borut Likar

University of Primorska, Slovenia

borut.likar1@guest.arnes.si

Collaboration between enterprises and public research organisations (PROS) is an important factor in the economic performance and development of a country. The said relates to the objective of the present study, in which we identified the effects, results, reasons for (non-)collaboration, and advantages/disadvantages of collaboration among enterprises and PROS from the perspective of enterprises and business clusters. Our results show that the reason behind enterprises and PROS working together is to achieve breakthrough results rather than financial gain. The obstacles hindering such university-industry collaboration include red tape, inadequate staff, low financial incentives, unawareness of calls for projects, and lack of initiative on behalf of Pros in establishing contacts. Among the most important effects of such collaboration are entry into new markets, progress in the field of human resources, and establishment of new partnerships. Less important effects include the establishment of start-ups and profits arising from patents and licenses. While the development of new products/services and their offer on the market are considered important, scientific achievements and granted patents are regarded as less significant results. University-industry cooperation should thus be improved by way of more frequent collaborations, knowledge exchange, liaison officers, streamlined administration, proper management of intellectual property rights, and increased public visibility.

Key Words: enterprises, PROs, collaboration, transfer of knowledge, business clusters

JEL Classification: 032

https://doi.org/10.26493/1854-6935.18.211-236 


\section{Introduction}

In this qualitative study we investigated how collaboration between enterprises and PROS on joint (Co-)financed R\&D projects (also through liaison institutions) affects their business performance and efficiency. This is influenced not only by financial resources, but also by human expertise, more advanced technology, R\&D, and enterprise strategy (Fatur and Likar 2009). The main feature of $\mathrm{R} \& \mathrm{D}$ is that it is implemented to create new knowledge, which is also the main result of its activities. Acquired knowledge can be focused on generating economic benefits, addressing societal challenges, or simply on generating knowledge per se (Organisation for Economic Co-Operation and Development 2015, 25). R \& D takes place in the form of basic and applied research, pre-competitive and industrial research and in the form of knowledge transfer ('Zakon o raziskovalni in razvojni dejavnosti' 2006). Therefore, we consider it important that the field of R\&D develops and expands especially attentively. In particular, human resources management, development and introduction of innovative technologies, management of intellectual property rights and (not only financial) investments in $\mathrm{R} \& \mathrm{D}$ are at the forefront.

We thought it sensible to analyse the topic in order to determine how (or if) the state's financial incentives aimed at fuelling R \& D affect the efficiency and effectiveness of collaboration between enterprises and public research organisations (hereinafter PROS) as the recipients of such incentives. We were interested in whether these enterprises are more successful and faster in developing and introducing new technologies and whether they are more capable of translating the results of (co-)financed R \& D projects into successful market products. Our interest was focused on the analysis of the effects of state subsidies in terms of enterprise size (micro and small, medium and large enterprises) and level of technological development (low-to-medium-tech enterprises, high-tech enterprises), whereby we observed the role of liaison institutions as an important link between enterprises and PROS. Furthermore, we paid special attention to the analysis of motives and reasons for (non-)collaboration between enterprises and Pros, and tried to determine the advantages, disadvantages, and results of these connections and formulate suggestions for their improvement.

The following paper is divided into sections; first, by way of reviewing and studying foreign and national professional literature and relevant online and other sources, we formed theoretical starting points and ex- 
plained the key concepts for the empirical part of the paper and analysis. In the empirical part of the research, which was conducted between October 2019 and March 2020, we described the methodology of work and sampling, while in the final analysis we presented the main obtained data in tables and additionally (also personally) interpreted them in the accompanying text. In summary, recommendations to companies and business clusters for further participation in joint $\mathrm{R} \& \mathrm{D}$ projects are presented.

The most important and significant contribution of this paper addresses the problem of efficient cooperation between PROs and industry. We focused on different aspects of cooperation, which will be presented. We will also tackle the main obstacles and key success factors for fruitful and long-term based cooperation.

\section{Theoretical Background}

RESEARCH AND DEVELOPMENT (R\&D)

Stanovnik and Uršič (2019) and Rodica, Vojnović, and Grujić (2014) state that $\mathrm{R} \& \mathrm{D}$ is the basis for promoting the technological development, competitiveness and innovativeness of individual enterprises and economies while the said $\mathrm{R} \& \mathrm{D}$ is also indirectly responsible for economic growth of individual enterprises and economies. In this context, the focus is on human resource management, development and introduction of innovative technologies, management of intellectual property rights, transfer of knowledge from public research organisations to the industry and vice versa, and (not only financial) investments in R\&D.

KNOWLEDGE TRANSFER BETWEEN BUSINESS SECTOR AND PROS

As pointed out by Likar ('Borut Likar: če ti v Sloveniji enkrat ne uspe, si že »luzer«' 2018), the willingness of enterprises to collaborate with competing enterprises as well as with partners from outside the industry, such as public research organisations (PROS), is an important factor in their viability and competitiveness. Henttonen, Kianto, and Ritala (2016) cite several authors when defining the term 'knowledge transfer' and they interpret knowledge transfer as the transfer of one's knowledge from that intended for an organisation into collective knowledge. While Lee et al. (2010) emphasise that knowledge exchange must benefit both the individual and the group; Hsu (2008) extends this definition with the condition that the process of knowledge transfer from the holder to the recipient 
allows for an enhanced and more effective work performance. It does not matter whether the knowledge transfer is intentional or unintentional, as long as there is a genuine interest in the transfer on both sides. Moreover, its speed and quality as well as continuity are also important factors. This results in increased knowledge value, along with continuous generation of new knowledge, which in turn advances innovation (Heisig et al. 2016).

\section{BUSINESS CONNECTIONS AND TECHNOLOGY TRANSFER OFFICES}

In Slovenia, technology transfer offices (hereinafter T TOS) in PROs are important agents in knowledge transfer and represent the link between enterprises and PROS. Their range of activities include preparation and placement of the researchers employed at PROS who are active in technological and market-relevant fields to work in enterprises in accordance with their needs and the needs of the industry. An important task of т т O is encouraging enterprises to extend the use of their services into facilitating access to knowledge and research equipment provided by PROs ( $\mathrm{Pal}$ 2017). т тоs therefore represent an adequate and suitable link between enterprises and PROs; however, in a survey conducted among 63 researchers at 22 universities in Ireland, New Zealand, and the United States, O'Kane et al. (2015) show that not even researchers themselves are familiar with the operation of such offices within colleges and faculties, which leads us to question the extent to which enterprises are aware of such services.

Stare, Bučar, and Udovič (2014) examine the results of connections between PROS and enterprises in Slovenia on the case of cooperation between enterprises and PROS through connecting institutions and find that setting common goals for enterprises and PROs facilitates cooperation, increases mutual trust, creates indirect knowledge and intangible capital, which is crucial for long-term cooperation, while also enabling the development of competent personnel and strengthening interdisciplinarity. Moreover, the share of high-tech products in exports and services based on more advanced skills are significantly strengthened. The importance of business clusters is also demonstrated by Strašek, Pušavec, and Likar (2020), who find that strategic partnerships increase the level of open innovation and bring about concrete economic and other nonfinancial effects. In this, it is necessary to take into account the specificities of monitoring the effects of business clusters, which need to be addressed through approaches different from those used for enterprises. This field 
is addressed in more detail by the monograph edited by Bučar, Črnigoj, and Lipnik (2020).

\section{COLLABORATION BETWEEN ENTERPRISES AND PROS}

According to Johnson and Tilley (1999), the first step towards a successful collaboration between a PRO and an enterprise is awareness of the existence of those PROs which are relevant to the business activity the enterprise is engaged in. It is necessary for the enterprise to recognise the importance of knowledge a PRO may contribute to its progress and development, and as pointed out by Zajc (2012), the reputation of a PRO within the economy and its marketing activities are of great importance as well. Furthermore, the first contact of an enterprise with a PRO depends on the level of formality or casualness of either party, and the approach chosen for the first contact may influence the climate of the entire collaboration. The same author (Zajc 2012) and Busom and Fernandez-Ribas (2008) note that larger companies often collaborate with PROs. The reason for this is that they have more resources (financial and human) which they can devote to such cooperation. Large enterprises should therefore be more aware of the benefits of working with capable P ROs. In terms of the degree of technological development, it is high-tech enterprises which should prioritise collaboration with PROS, as this creates a more complex business environment.

\section{Motives for Collaboration}

Perkmann, King, and Pavelin (2011) point out that enterprises and PROS cooperate for a variety of reasons. In the context of such collaboration, PROS primarily seek to gain additional resources for collaboration and make such cooperation conditional on the complementarity of their academic work with the industry they wish to collaborate with. Enterprises, on the other hand, seek access to academic and professional knowledge offered by the PROs, and primarily wish to develop new products or services with their help and experience in $\mathrm{R} \& \mathrm{D}$. The same authors (2011) also note that the more reputable the PRO, the sooner an enterprise decides to enter into such collaboration.

Through a survey on the case of Germany and France, Robin and Schubert (2013) find that cooperation between enterprises and PROs significantly strengthens innovation at enterprises. Lesjak (2019) focuses on the social effects of cooperation between enterprises and PROs, emphasising the importance of knowledge which PROs provide to enterprises for 
$\mathrm{R} \& \mathrm{D}$ purposes and vice versa. The author also finds that the possibility of sharing technological equipment is an important factor of cooperation, that cooperation based on co-funded projects is often the entry point into niche areas of technology, and that publicly accessible research articles can support industry as well as start-ups.

\section{Reasons for Non-Collaboration}

Zajc (2012) further notes that one of the reasons for the lack of cooperation between enterprises and PROs may be a lower level of educational attainment of enterprise managers (over half of them being secondaryschool graduates). Although they are familiar with the PROs they could collaborate with, their lack of previous contact with these institutions means they have no suitable acquaintances or interlocutors within the institution. The same author (2012) concludes that enterprises with no prior experience of such collaboration are less likely to recognise the need to connect with PROS. In a study examining why PROs in Italy (do not) choose to work with enterprises, Tartari and Breschi (2012) state that as the factor which hinders cooperation the most is the fact that PROs fear losing intellectual freedom. Enterprises and PROs expect collaboration to bring about certain benefits. These benefits, as listed by Ankrah et al. (2012), include: financial/economic advantages (joint development is cheaper than individual development, government incentives in the form of subsidies and tax exemptions are easier to obtain (as well as more substantial), organisational advantages (e.g., mutual exchange of staff and establishment of spin-offs and start-ups) and social benefits (references of such cooperation increase both entities' social responsibility, resulting in economic and social progress of the environment both entities are located in, while joint academic publications contribute to increased reputation of companies and PROS).

\section{Barriers for Collaboration}

Pronk et al. (2015) identify various barriers which may make it difficult for PROS and enterprises to collaborate. These relate to the protection of intellectual property, being limited in setting priorities, and incompatibility of interest (education against commercial interests), limited (or too much) time required for collaboration, inflexibility of an entity, limited competence and (lack of) ability to cooperate with other partners. Muscio and Vallanti (2014) supplement this list of barriers with a potential mismatch of incentives between enterprises and PROs (one entity may 
be more motivated to collaborate than the other), lack of suitable intermediaries (as well as levers and comprehensible procedures) in the two entities, which may lead to problems in interaction and networking, and a mismatch between the academic objectives of researchers and the actual business needs of enterprises.

\section{SITUATION IN SLOVENIA}

Countries which invest heavily in $\mathrm{R} \& \mathrm{D}$ are more competitive in the marketplace than those which invest less, and their performance in various sectors (health, transport, digitisation, environment, energy, social services, etc.) helps build a better society (European Commission 2014).

$\mathrm{R} \& \mathrm{D}$ in Slovenia is carried out by research organisations or private researchers in the form of programmes and projects in accordance with the 'Resolution on the Research and Innovation Strategy of Slovenia 20112020' (ReRISS). The aim of the strategy is to facilitate a higher quality of life for all, while achieving higher value added per employee, achieving a higher share of technological and non-technological innovations, providing more quality jobs and thus raising the competitiveness of the economy (Reriss).

The latest available report on the implementation of ReRIss for the 2015-2017 period (Vlada Republike Slovenije 2019) provides findings on the implementation of key success factors (management of research and innovation system, investment in science and innovation, human resources, open, excellent and attractive system, research efficiency innovation activities and effects on the economy), which are not encouraging for the further development of $\mathrm{R} \& \mathrm{D}$ in Slovenia. Compared to the situation before the adoption of the RerIss (before 2011), Slovenia has deteriorated its research and innovation position in the European Union (EU) during its implementation period, despite different commitments. According to the Office of the Republic of Slovenia for Macroeconomic Analysis and Development (Urad Republike Slovenije za makroekonomske analize in razvoj 2019), Slovenia ranks in the group of strong innovators according to the European Innovation Index (EII) within the Central European Member States, although lagging behind the average in 2010-2017.

According to the latest data from the World Economic Forum (Schwab 2019), in 2018, Slovenia ranked 28th in terms of innovation and 27th among 141 countries recorded in statistics. Hence, Slovenia appertains to the group of innovative 'follower' countries, i.e. countries that lag behind 
other countries in terms of innovation results. In 2019, according to the global innovation index, Slovenia ranked 32nd among 131 countries surveyed, which is one place lower than in the preceding year (Dutta, Lanvin, and Wunsch-Vincent 2019).

The reasons behind this situation may be found in the decrease in funding for R\&D (Vlada Republike Slovenije 2019, 154-5) as gross domestic R \& D in Slovenia in 2018 according to final data, amounted to EU R 892.7 million, which is $11.3 \%$ more than in 2017 (Statistični urad Republike Slovenije 2020). However, Slovenia has moved away from the common European goal. In the 2010 strategy 'Europe 2020: A Strategy for Smart, Sustainable and Inclusive Growth' (European Commission 2010), the EU aimed at allocating $3 \%$ of its GDP to R \& D by 2020 ( $1 \%$ to publicly funded and $2 \%$ to privately funded $\mathrm{R} \& \mathrm{D}$ ). According to the Statistical Office of the Republic of Slovenia (Statistični urad Republike Slovenije 2020 ), Slovenia allocated only $2 \%$ of its GDP to R\&D in 2018 . The majority of R\&D funding came from the business sector (1.4\% of GDP allocated to $\mathrm{R} \& \mathrm{D})$.

Investments in $\mathrm{R} \& \mathrm{D}$ are also key to the success, innovation and competitiveness of companies. Results from research which was conducted by Carboni (2017) showed that enterprises which receive public aid invest more in $\mathrm{R} \& \mathrm{D}$. In order to establish the competitiveness of companies, the competent institutions (SPIRIT Slovenia, the Slovenian Enterprise Fund and SID Bank with the support of MGRT) are tendering grants. The aim of these tenders is to integrate the Slovenian economy into international scientific research programmes, create new jobs, promote innovation practices and create innovation infrastructure (Ministrstvo za gospodarski razvoj in tehnologijo Republike Slovenije 2019).

Based on her own research, Krošelj (2019) set out the effects of the P2 subsidy (a subsidy from the Slovenian Entrepreneurship Fund for the launch of innovative projects) on the company's business performance and the number of jobs. The author conducted the research on the basis of a comparative analysis of secondary data. It included 280 companies in the sample, of which 130 were subsidised companies and 150 companies did not receive a subsidy. The performance of companies was determined on the basis of the financial indicator of value added per employee and the number of jobs in relation to the amount of the subsidy received. She studied the data over a period of one year before receiving the subsidy and three years after receiving the subsidy. The results showed that the amount of the subsidy was not positively related to the growth of the com- 
pany's performance, which was measured by value added per employee, and the amount of the subsidy was not positively related to job growth. This means that the performance of companies is influenced not only by financial resources, but also by people's knowledge, more advanced technology, research and development, company strategy and more.

\section{Methodology}

This study presents and interprets the data obtained in the period between October 2019 and March 2020, when we conducted a qualitative examination and analysis of cooperation between enterprises and PROS on joint (co-)financed $\mathrm{R} \& \mathrm{D}$ projects. Two questionnaires consisting of approximately 20 questions were prepared; the first one was administered to a non-random sample of subjectively selected Slovene enterprises, and the second one was administered to business clusters, which were selected in the same manner and which represent an important link between enterprises and PROS. It was their views that we were particularly interested in. In terms of size, the enterprises were classified into as large, mediumsized and micro/small enterprises and as low-to-medium-tech and hightech in terms of technological development - we mainly looked for those who received assistance in the form of public funding. According to their size and level of technological development, the enterprises were divided into matrix groups in order to obtain as evenly distributed data as possible according to the stated features. The minimum number of respondents was estimated at $1-3$.

The data obtained were used to conduct a qualitative analysis according to the presented content sets and according to the matrix (table 1) of the participating enterprises and business clusters. The questionnaires consisted of open-ended as well as close-ended questions. The descriptive data obtained were additionally presented. Where numerical data were obtained, averages were calculated and data were additionally interpreted. Table 1 shows the division by level of enterprise according to their size and technological development, the abbreviations used, the number of respondents included in the analysis, and the illustration and number of business clusters included.

The questionnaire included closed and open-ended questions. In case of the former, the respondents were offered a certain number of answers to choose from, with answers limited to only one possible answer, or were asked to sort the provided answers by order of importance. We obtained numerical data, for which we calculated the averages and provided a de- 
TABLE 1 Illustration of Examined Enterprises

\begin{tabular}{|c|c|c|}
\hline \multirow[t]{2}{*}{ Size of enterprise } & \multicolumn{2}{|c|}{ Technological development } \\
\hline & High-tech enterprises & $\begin{array}{l}\text { Low-to-medium technology } \\
\text { enterprises }\end{array}$ \\
\hline Micro enterprise & $\begin{array}{l}\text { Micro/small-sized high-tech } \\
\text { enterprise (ME-HT), } n=13\end{array}$ & $\begin{array}{l}\text { Micro/small-sized low-to- } \\
\text { medium technology enterprise } \\
(\text { ME-LMT), } n=4\end{array}$ \\
\hline $\begin{array}{l}\text { Medium-sized } \\
\text { enterprise }\end{array}$ & $\begin{array}{l}\text { Medium-sized high-tech enter- } \\
\text { prise (MSE-HT), } n=6\end{array}$ & $\begin{array}{l}\text { Medium-sized low-to-medium } \\
\text { technology enterprise (MSE- } \\
\text { LMT), } n=11\end{array}$ \\
\hline Large enterprise & $\begin{array}{l}\text { Large high-tech enterprise (LSE- } \\
\mathrm{HT} \text { ) }, n=10\end{array}$ & $\begin{array}{l}\text { Large low-to-medium technology } \\
\text { enterprise (LSE-LMT), } n=3\end{array}$ \\
\hline Business Clusters & & $=8$ \\
\hline
\end{tabular}

scriptive explanation of the results. In open-ended questions, we asked respondents to provide answers at their own discretion, and we asked them for at least three statements. The answers were summarised and further interpreted.

The questionnaire which we designed for enterprises contained 19 questions. It was distributed via an e-mail account (set up specifically for this study) to more than 300 Slovenian enterprises, which we subjectively selected from those listed on the bizi.si website (https://www.bizi.si) depending on their size. Another questionnaire containing 14 questions was sent to a total of 43 business clusters. We also chose these subjectively, as we had a very limited base of potential respondents, so we knew exactly and in advance to whom we were sending the questionnaire. The data on business clusters were obtained from the website of the Chamber of Commerce and Industry of Slovenia - Gospodarska zbornica Slovenije (https://www.gzs.si/) and the website of the Public Agency of the Republic of Slovenia for the Promotion of Entrepreneurship, Internationalization, Foreign Investment and Technology - SPIR I T Slovenija (https://www.spiritslovenia.si/). A total of 55 respondents completed the questionnaires; 47 came from enterprises and 8 from business clusters. We present them separately.

\section{Presentation of Results and Data Analysis}

The first section, entitled Data Analysis - Enterprises, presents and analyses the data obtained through the questionnaire administered to enterprises, and the second, entitled Data Analysis - Business Clusters, 
presents the data obtained from business clusters. In the following paragraphs, we present both in detail. The answers to the questions are organised into meaningful sections, while the results and effects of collaborations are outlined in more detail and followed by the interpretation of responses to other questions which we also asked our respondents.

\section{DATA ANALYSIS - ENTERPRISES}

In the first set of questions, we asked enterprises to specify their size, technological development and classification according to the Standard Qualification of Activities (SQA). We were particularly interested in the share of enterprises participating or having participated with PROS in cofinanced R\&D projects. In terms of size, $36 \%$ identified themselves as a micro/small-sized enterprise, $36 \%$ as a medium-sized enterprise and $28 \%$ as a large enterprise. In terms of technological development, $37 \%$ of enterprises identified themselves as a low-to-medium tech enterprise and $63 \%$ as a high-tech enterprise. According to the SQA, enterprises were most often classified as belonging to the $\mathrm{C}$-manufacturing sector. Over the last 5 years, $65 \%$ of respondents have participated in $\mathrm{R} \& \mathrm{D}$ projects connecting industry with public institutions through (co-)financed projects, while $35 \%$ of respondents have not.

\section{Reasons for Participation}

The next set of questions referred to the reasons and motives of enterprises for (non-)cooperation with PROS. In this context, we were interested in how the respondents chose the PRO they cooperated or had cooperated with. Based on their answers, we concluded that there is no interest on the part of enterprises to collaborate with PROS, nor do they feel the need for such collaboration, and also that they have not found or been aware of suitable calls for projects and cooperation which would suit their interests. They highlighted the unresponsiveness and financial incompatibility on the part of PROs. Notably, enterprises, regardless of their size and technological development, chose as the main reasons for collaborating with PROs those options which they believed would facilitate their own advancement (in terms of development, technology, human resources). We can say that the respondents assessed such long-term reasons for cooperation as more important. Financial benefits, which can be regarded as a short-term effect, were ranked at the bottom of the scale. The answers of all groups of respondents about the ways of selecting the PRO to collaborate with in the context of (co-)financed projects show 
quite uniformly that previous collaborations, acquaintances and previously established relationships are the most common reasons for repeat collaborations between enterprises and PROS.

\section{Benefits, Opportunities and Suggestions for Improvement}

The main questions in the questionnaire addressed the benefits of cooperation, opportunities to improve cooperation, obstacles and suggestions for improvement. Respondents provided answers from their own perspective, as well as from PROs and the state. As the main advantage of cooperation between enterprises and PROs, the respondents mentioned the possibility of acquiring and transferring knowledge from practice into theory and vice versa, the possibility of sharing research equipment, developing new products, and taking advantage of greater funding opportunities. They believed that the state would gain from employment (creation of new high-tech jobs), taxes, as well as general and technological development. The state also welcomes and facilitates the networking between enterprises and PROs and provides funding for such collaborations. Enterprises provided numerous suggestions for improving cooperation with PROs: they wish for more active cooperation with PROS, as this would help extend their expertise from the industry into education and vice versa, encourage innovation within enterprises, aid human resource development in terms of educational structure, and increase the opportunities to connect with other enterprises. Enterprises expect PROS to be more active and show interest in establishing partnerships with industry, to be more interested in transferring knowledge and encouraging innovation in enterprises. PRos could establish partnerships with enterprises on their own and thus acquaint students and young researchers with the actual problems enterprises are faced with. The state could help improve such cooperation by cutting red tape, adjusting legislation, encouraging intense networking pathways, and providing more (and higher) financial incentives (including those aimed towards innovation and entrepreneurship). Enterprises, regardless of their size and technological development, listed similar barriers to working with PROs; they experience too many problems and are overwhelmed by bureaucracy (this was often stated by low-tech enterprises), while (according mainly to high-tech enterprises) PR Os are too slow, devote too little time to joint projects and generally possess (too) little practical knowledge. Enterprises blame the state for excessive bureaucratic requirements, regulations and conditions, and for insufficient competence of staff employed 
TABLE 2 Results of Cooperation between Enterprises and PRO

\begin{tabular}{lc}
\hline A new joint venture was formed & 9.6 \\
Scientific publications and citations & 7.4 \\
Granted patents & 7.3 \\
New business opportunities have opened up & 5.9 \\
We have established a long-term, strategic partnership & 5.4 \\
Our employees have gained additional qualifications & 5.4 \\
We have been invited to establish new project partnerships & 5.2 \\
We have established new business contacts & 4.7 \\
We have established cooperation in the use of R\&D equipment & 4.6 \\
The absorption capacity of the enterprise has increased & 3.8 \\
We have developed new products and offered them on the market & 2.6 \\
\hline
\end{tabular}

NOTES 1 - most important, 11 - least important.

in the areas of cooperation between industry and PROS. Respondents felt that cooperation with PROs lacked networking, cooperation and mutual assistance from all three types of entities (enterprises, PROs and the state), especially in the field of knowledge and human resources; such suggestions for improvement were repeatedly offered by high-tech enterprises. Low-tech enterprises, on the other hand, wish to see improvement in the financial field in particular. All matrix groups proposed a higher level of integration into associations and the need to exploit the potential and purpose of such associations, a more active engagement of PROS in the practical aspects of the industry and the need for PROs to pay attention to the actual needs of enterprises, as well as streamlined tendering processes and more financial resources allocated by the state.

\section{Results and Effects}

The penultimate set of questions in the questionnaire referred to the results and effects of collaborations. Table 2 shows how, on average, respondents ranked the given responses associated with the results of their cooperation with PROs by order of importance. The responses of individual matrix groups showed that the matrix groups were in agreement when determining the most and least significant results; the statement 'We have developed new products and services and offered them on the market' was mostly placed in one of the first three places, and the statement 'A new joint venture has been created' was ranked last or next to last.

In this set of questions, we were also interested in how enterprises de- 
TABLE 3 Achieved Effects of Cooperation with PROS in R\&D Programmes

\begin{tabular}{lc}
\hline New spin-offs and start-ups & 5.5 \\
Entering new markets & 4.1 \\
Change in export volume as a result of R\&D project & 3.7 \\
$\begin{array}{l}\text { Change in value added per employee after the implementation of a co-financed } \\
\text { project }\end{array}$ & 2.4 \\
$\begin{array}{l}\text { Presentation of new more technologically demanding projects } \\
\text { Number of new jobs created and their structure as a result of participation in }\end{array}$ & 2.3 \\
the measure (type, complexity ...) & 2.2 \\
\hline
\end{tabular}

NOTES 1 - most important, 6 - least important.

fined the management and ownership of newly created intellectual property rights (hereinafter IP rights). Respondents, regardless of their size and technological development, defined the management and ownership of the newly created IP rights, which remained in the enterprise or were managed under previous contracts, in a similar way. Respondents were also asked about the achieved level of technological development (hereinafter TD), whereby we found that, on average, enterprises participating in (co-)financed projects achieved all levels of TD (most often TD 6 and TD 9), with high-tech enterprises achieving higher levels of TD than lowtech ones.

Table 3 illustrates how enterprises ranked the effects achieved in cooperation with PROS on (co-)financed projects by order of importance. Based on the data obtained from the matrix groups, we learned that lowtech enterprises gave priority to those options which represented effects in the field of human resources and employment, as they ranked the reasons 'Change in value added per employee after the co-financed project' and 'Number of new jobs and their structure, as a result of participation in the measure (type, complexity, education)' higher than high-tech enterprises. High-tech enterprises, on the other hand, chose 'Presentation of new more technologically demanding projects' as the most important effect. Respondents did not see the effect 'Entering new markets' as important (except LSE-LMT, which ranked it as third), nor did they define the effect 'New spin-offs and start-ups' as insignificant.

Table 4 illustrates how respondents ranked indirect effects of working with PROs by order of importance. The results show that all respondents, regardless of their size and $\mathrm{TD}$, perceive those effects which involve some form of cooperation in the market among themselves or with external 
TABLE 4 Indirect Effects of Cooperation between Companies and PROS

\begin{tabular}{lc}
\hline Revenues from the sale of own patents and licenses before and after the project & 4.7 \\
Volume of purchase of foreign licenses before and after the project & 4.1 \\
Increasing competitiveness & 2.0 \\
Increased trust between R\&D project partners & 2.0 \\
New business collaborations and partnerships & 1.9 \\
\hline
\end{tabular}

NOTES 1 - most important, 6 - least important.

partners as more important indirect effects. The benefit of patents and licenses (own or purchased) was perceived as a less significant indirect effect of collaborating with PROs.

\section{Long-Term Effects}

The last set of questions referred to the cooperation between enterprises and PROs after the completion of (co-)financed projects. Respondents' answers indicate that enterprises which have participated (or are participating) in joint projects with PROS continue this cooperation in the form of new projects and in the form of development and final production of the desired products. In cases when joint projects have been completed, there is also a desire for repeat collaboration and joint product development (strategic partnerships, contractual cooperation, etc.), or at least participation in testing, analysis, etc. Based on the answers given, we can conclude that all respondents have participated in joint projects which lasted for at least one year, some for over 5 years (or even up to 15 years). We were interested in why they had not continued collaborating on subsequent projects; the companies stated that they had not yet completed the existing collaboration with the PRO or that they no longer had the need for such collaboration.

\section{DATA ANALYSIS - BUSINESS CLUSTERS}

The first set of questions was general; we were interested in which business clusters they TD of the enterprises participating in their cluster. Respondents mostly identified themselves as strategic research and innovation partnerships ( $75 \%$ and 6 respondents, respectively), one respondent identified themselves as a cluster (13\%) and one (centre of excellence) as other (13\%). Respondents stated that most of their connections are micro and small enterprises (40.3\%), 24.4\% are medium-sized enterprises, $23.5 \%$ are large enterprises, and $\mathbf{1 2 . 5} \%$ are PROs. High-tech enterprises ac- 
count for a larger share in business clusters, namely a total of $52.3 \%$, while low-tech enterprises account for $47.7 \%$.

\section{Reasons for Participation}

In the second set of questions, we asked about the motives and reasons for cooperation between enterprises and PROs through business clusters. We were interested in the reasons for non-cooperation. Respondents cited 'Perceived technological/R \& D/innovation potential for breakthrough results' as the most important motive for cooperation between PROs and enterprises, and they also considered 'Perceived opportunity to finance joint development' an important motive. They did not regard the motives 'Clearly justified need/opportunity in the international market' or 'Appropriate staff or the lack thereof in the enterprise' as important, while 'Financial benefits' was regarded as an even less important motive for cooperation. Business clusters stated that, in their view, enterprises and PROs did not connect through them due to the complex bureaucracy, burdens on existing staff or lack of suitable and experienced staff (either by enterprises or PROs), fear of disclosure of know-how, unfair competition and insufficient financial resources from the state. They also felt that enterprises were too slow to cooperate and did not trust public institutions, and that the state did not have adequate funding mechanisms in place, which would include the co-creation of strategic documents by enterprises.

\section{Advantages, Opportunities and Barriers to Cooperation}

The third set of questions was aimed at identifying strengths, possibilities for improvement and barriers to cooperation. Respondents stated that cooperation between enterprises and PROs through business clusters was good. They opted for this option in $50 \%$ of all cases. A quarter of the respondents believed that such cooperation was very good, and a quarter stated that it was neither good nor bad. On average, the respondents identified 'Newly established and expanded partnerships' as the most important advantage of cooperation between enterprises and PROS through business clusters. They also considered 'Joint Innovation Activities' to be an important reason for cooperation. They perceived the reasons 'Investments in projects in which various partners participate' and 'Joint activities in the field of exports' as the least important. Respondents stated that the role of business clusters could be improved by giving cluster members priority in calls for projects, making partnerships more in- 
terdisciplinary, and encouraging participation of enterprises in decisionmaking. They emphasised the importance of enterprises in clusters, and stated that associations should emphasise their role as facilitators, and that they should also be able to have access to more co-financing. They proposed decreasing the administrative complexity of project management and introducing a voucher system through an intermediary, greater public visibility and more tax relief. Priority areas should also be considered by the Slovenian Research Agency (A R Rs), and establishing connections with enterprises and mutual cooperation should be set as one of the criteria for obtaining funding. According to the respondents, the weaknesses of connecting enterprises and PROS through business clusters are excessive paperwork, bureaucracy, poor co-financing, and too much theory in writing reports. Business clusters have insufficient influence on the conditions of calls for projects, insufficient integration of horizontal key technologies, operation without a clear focus of content, etc.

\section{Results and Effects of Cooperation}

In the central set of questions, we asked business clusters about the results and effects of the cooperation between enterprises and PROs which take place through them. Table 5 shows the respondents' answers regarding the most and least important results. Respondents ranked the result 'New products and services and their offer on the market' the highest in terms of importance. The least important result of cooperation was 'Cooperation in the sharing of $\mathrm{R} \& \mathrm{D}$ equipment.' Less important results were: 'The creation of a new joint venture, 'Granted patents' and 'Scientific publications and citations.' We find it interesting that the respondents emphasise the importance of long-term cooperation and partnerships, but do not perceive joint ventures and the sharing of equipment (which can also be a form of long-term cooperation) as important.

Table 6 shows the ranking of the achieved effects of cooperation between enterprises and PROS through business clusters. Respondents stated that the effects of cooperation between enterprises and PROs through business clusters with the help of public funds are reflected in the change in value added per employee and in newly opened opportunities in the market. The achieved effects in the field of market, personnel, development or pedagogical cooperation between enterprises and PROs were not identified as significant.

Respondents evaluated 'Increased trust between R\&D project partners' as the most important indirect effect of cooperation between enter- 
TABLE 5 Results of Cooperation between Enterprises and PROS through Business Clusters

Cooperation in the use of $\mathrm{R} \& \mathrm{D}$ equipment 10.0

$\begin{array}{lr}\text { Scientific publications and citations } & 9.8\end{array}$

$\begin{array}{lr}\text { Granted patents } & 8.8\end{array}$

$\begin{array}{ll}\text { The creation of a new joint venture } & 8.5\end{array}$

$\begin{array}{ll}\text { Additional qualifications of employees } & 7.0\end{array}$

$\begin{array}{ll}\text { New project partnerships } & 6.0\end{array}$

New business contacts $\quad 4.5$

More effective implementation of R\&D achievements 3.5

$\begin{array}{ll}\text { New long-term strategic partnership } & 3.3\end{array}$

$\begin{array}{ll}\text { New business opportunities } & 2.8\end{array}$

\begin{tabular}{ll} 
New products and services and their offer on the market & 2.0 \\
\hline
\end{tabular}

NOTES 1 - most important, 11 - least important.

TABLE 6 Achieved Effects of Cooperation between Enterprises and Pros through Business Clusters

New spin-offs and start-ups

Direct effects that PPA can also use elsewhere (pedagogical work, other mar-

keting activities, $\mathrm{R} \& \mathrm{D}$ achievements, etc.)

Number of newly created jobs and their structure as a result of participation in the measure (type, complexity ...)

Change in export volume as a consequence of the R\&D project 3.8

Presentation of new technologically more demanding projects 3.3

Entering new markets $\quad 2.3$

Change in value added per employee after the implementation of a co-financed $\quad 2.0$ project

NOTES 1 - most important, 7 - least important.

prises and PROS. Indirect effects 'Volume of purchase of foreign licenses before and after the project' and 'Revenues from sale of own patents and licenses before and after the project' were seen as the least important. Respondents were also asked about the additional effects of cooperation between enterprises and PROS through business clusters with the help of public funds (compared to the situation where the enterprise and the PRO collaborated independently and not under the auspices of a business cluster). According to them, these are: 'newly formed links between enterprises inside and outside the areas of operation,' 'the emergence 
of collaborative thinking about pilot equipment that benefits the majority' and similar 'participation in applied research at an early stage of development.' Respondents believe that cooperation brings an increase in added value and that a major breakthrough in the field of competencies has been achieved as part of cooperation. Enterprises can achieve better business results, enter new global markets, improve business models, develop faster, and conduct more applied research in cooperation with PROS, who can in turn obtain a larger volume of projects, invest more in $\mathrm{R} \& \mathrm{D}$ activities, while joint consortia have more power of obtaining new projects.

\section{Long-Term Effects}

The last few questions in the questionnaire referred to future cooperation. All respondents stated that the cooperation between themselves, the enterprises and PROS continued even after the completion of (co-)financed projects. Cooperation continues either in the form of new, direct, joint projects or only in the form of collaboration within EU projects. Together, they also take the initiative to legislators, as they believe they can achieve more, the burden-sharing is lower and the overall benefit is greater. Cooperation also continues in the form of counselling offered to members of informal partnerships, exchange of information and in the form of organising regular meetings.

\section{Discussion}

\section{REASONS FOR (NON-)COLLABORATION}

- From the answers of both types of entities, it can be concluded that the types of enterprises which tend to establish partnerships with PROs more often are large enterprises and high-tech enterprises.

- Both enterprises and business clusters identified the achievement of breakthrough results as the main reason for establishing cooperation between Pros and enterprises. The answers of business clusters seem surprising, as they, unlike enterprises, do not assign much importance to human resources and international connections. In our opinion, long-term effects of human resource development and opportunities on the international market in connection with the achievement of breakthrough results lead to progress in enterprise development and competitive edge. 
- Financial benefits were identified by both entities as the least important reason for cooperation.

- Enterprises which had not participated in joint projects with PROS felt that they did not feel the need for such collaboration or did not know of appropriate or suitable calls for projects. We found the answer of one respondent that 'they were not invited to participate' interesting. While this may indicate certain passivity on the part of PROS in establishing contacts with enterprises (the reason 'due to slow response' could also be included into this category), it could also imply that enterprises are not familiar with suitable PROs with which they could establish contacts and consequently enter into collaboration.

- Enterprises also report incompatibility with PROS and even their unresponsiveness, lack of practical knowledge, rigidity and lack of initiative to establish connections with enterprises. Here we see an opportunity for PROs to become more involved in establishing contacts with enterprises. In our opinion, business clusters should take the initiative and encourage their members to cooperate with each other, strive to develop diversely trained staff, help PROs and enterprises in achieving these goals and consequently ensure their integration into the economy.

\section{SHORTCOMINGS, OBSTACLES AND OPPORTUNITIES}

- Both groups of respondents identify similar shortcomings with regard to cooperation between enterprises and PROs, whereby bureaucratic hurdles faced by enterprises stand out.

- Both groups mention unsuitable staff employed by the state and believe that the financial incentives they could jointly obtain are too low. Business clusters believe that the situation could be improved by introducing certain advantages for their members who would benefit compared to non-members (for example, higher financial incentives, tax relief, and joint decision-making in co-creating strategic documents). They also emphasise the more active role of enterprises in collaborating with PROS, which was also pointed out by the enterprises themselves. They are also in favour of more frequent collaborations; however, there should be more initiative from PROs, who could also offer their knowledge in the form of collaboration with students and young researchers. It should be recalled at this point 
that while enterprises call for more cooperation, they do not identify any suitable mechanisms to facilitate such cooperation. Business clusters also believe that the mechanisms and possibilities for connecting enterprises and PROs are insufficiently recognised by the public and therefore call for measures which would remedy this situation. Enterprises are also critical of their own non-inclusion in business clusters.

- According to enterprises, the least important way of establishing connections is through ттоs, which is surprising, as this is their main purpose. Although respondents did not provide any reasons as to why they did not use their help in establishing connections with PROS, we may conclude that the reasons for this may lie in extensive bureaucratic requirements, anonymity and lack of familiarity with their work.

- This is also confirmed by the responses of the enterprises from the first analysis, as the respondents viewed past contacts and personal acquaintances as more beneficial in establishing connections with PROS. It is also evident that many enterprises lack such foundations and are not familiar with the operation of PROS, nor do they have a network of useful acquaintances from the past (the reason for this may lie in the secondary-school level of education of managers). The opinion of enterprises regarding the unsuitable staff they need to deal with when establishing contacts and coordinating cooperation, due to the lack of trust in public institutions as recognised by business clusters, is not surprising. We find it interesting that enterprises list unsuitable staff only on the part of Pros, however they themselves do not recognise a similar situation in their own organisation, which is why we find that incentives (financial, practical, and advisory) aimed at training (employment) of suitable staff would also be welcome in enterprises. Here again, we wish to emphasise the importance and role of business clusters, which we agree are not sufficiently recognised by the public, and we also believe that enterprises in particular are not sufficiently aware of the benefits of membership in clusters.

\section{RESULTS AND EFFECTS}

- Both types of entities view the networking and linking of PROs and enterprises as positive, as it enables progress in innovation and in the exchange and dissemination of knowledge. 
- Both groups of respondents identified the development of new products and services and their offer on the market as the most important results of cooperation between enterprises and PROs. Business clusters emphasised the importance of new business opportunities, long-term collaborations and strategic partnerships, while enterprises considered the creation of joint ventures (i.e., long-term strategic partnerships) to be an insignificant result of cooperation with PROS.

- Both groups of respondents see scientific achievements and granted patents as irrelevant results of such cooperation. At this point, there seems to be a noticeable lack of interest in human resource development both on the part of enterprises and business clusters. Ignoring researchers' scientific achievements and not paying attention to IP rights management can lead to a lack of interest in establishing connections and creating results, as researchers do not make progress in personal development through actual engagement with industry, which can be confirmed by a patent or scientific publication.

- The answers of both groups of respondents show that the most important effects of cooperation between enterprises and PROs relate to employees: increased added value per employee, increased number of new jobs, increased demands in the workplace, and higher educational qualification of employees. However, these effects are recognised as more important only by enterprises, especially medium and low-tech ones. Business clusters, meanwhile, believe that a more important effect of cooperation is entering new markets.

- Both groups of respondents think that an important effect of cooperation is the establishment of new contacts, new partnerships, and increased trust between the two agents, which leads to longer-term cooperation. It is interesting to note that both groups of respondents agree that the long-term effect of establishing start-up and spin-off enterprises is a less significant or insignificant effect of cooperation. They also share the opinion regarding the benefits of patents and licenses (their own or purchased ones). This surprises us mainly when it comes to business clusters, as they rate increased competitiveness as an important effect of cooperation and, conversely, the use of acquired knowledge for educational purposes as an insignificant one. In our opinion, this makes an important contribution to increased 
competitiveness and is part of ensuring innovative development and advanced thinking in enterprises.

- Judging by the answers given by enterprises, they are not sufficiently aware of the importance of IP for innovative business and entering international markets. Business clusters are not helpful in this. They rated cooperation between enterprises and PROs through business clusters as important and beneficial in several aspects; new connections and cooperation mean improved business results and greater progress in the field of competencies. According to the clusters, such cooperation reflects higher investments in development and applied research for both enterprises and PROs, as well as an increased volume of new projects in general.

\section{LONG-TERM EFFECTS}

- After the completion of joint projects, enterprises and PROs undertake repeat collaborations either in the form of new work on projects or in the form of product development and final production. Enterprises also want the help of PROS in the field of analysis and testing. Business clusters help them establish new contacts, submit joint initiatives to legislators, assist with undertaking E $\mathrm{U}$ projects or sustaining the existing collaborations by organising informal meetings. According to enterprises, collaborations with P ROs usually last for the duration of the joint project, while some extend this cooperation to more than 10 years.

\section{Conclusion}

As part of the research, it was found that public investment in $\mathrm{R} \& \mathrm{D}$, in conjunction with PROS, is certainly welcome and has important effects on better innovation, competitiveness and the ultimate successful performance of companies. There is still a lot of room to improve these collaborations, which in turn entails benefit for both actors, especially in the greater involvement of them both, their willingness to participate more often and to exchange broader and different theoretical and practical knowledge. The findings of the research also showed that easing bureaucratic requirements and reducing administration would in many ways contribute to more effective cooperation. At this point, we propose also the education and employment of suitable liaison staff by companies, and on the part of PROS, an appropriate promotion of technology transfer offices. Their role should also be more distinct in explaining the 
importance of intellectual property rights, granted patents and the scientific achievements of the researchers involved, while the importance of acquired new knowledge for the education of future employees should be better recognised. We suggest that companies and business associations consider the importance of spin-off companies and more active involvement in this area of cooperation.

We can conclude that the cooperation between PROs and the economy brings a number of positive effects, which differ slightly between high and low and medium-tech companies, and at the same time there are even more opportunities to improve cooperation or more efficient use of public funds.

\section{Acknowledgments}

Umbrella project: CRP V5-1706 (April 2018-March 2020). Analysis of the efficiency of investments in research and development in Slovenia (AEI$R \& D-S L O)$.

\section{References}

Ankrah, N., T. F. Burgess, P. Grimshaw, and N. E. Shaw. 2012. 'Asking Both University and Industry Actors About Their Engagement in Knowledge Transfer: What Single-Group Studies of Motives Omits.' Technovation 33 (2-3): 50-65.

'Borut Likar: če ti v Sloveniji enkrat ne uspe, si že »luzer «'. 2018. u pbudi, 12 January. https://upbudi.upr.si/si/mnenja/borut-likar-ce-ti-v-slovenijienkrat-ne-uspe-si-ze-luzer

Bučar, M., M. Črnigoj, and A. Lipnik, eds. 2020. Vrednotenje sodelovanja med znanostjo in gospodarstvom. Ljubljana: Založba FDV.

Busom, I., and A. Fernandez-Ribas. 2008. 'The Impact of Firm Participation in R\&D Programmes on R\&D Partnerships.' Science Direct Research Policy 37 (82): 240-57.

Carboni, A., O. 2017. 'The Effect of Public Support on Investment and R\&D: An Empirical Evaluation on European Manufacturing Firms.' Technological Forecasting and Social Change 117 (c): 282-95.

Dutta, S., B. Lanvin, and S. Wunsch-Vincent, eds. 2019. The Global Innovation Index 2019: Creating Healthy Lives - The Future of Medical Innovation. 12th ed. Ithaca, NY: Cornell University; Fountainbleu: INSEA D; Geneva: World Intellectual Property Organisation.

European Commission. 2010. 'Europe 2020: A Strategy for Smart, Sustainable and Inclusive Growth.' со M(2010) 2020 final, European Commission, Brussels. 
- 2014. Open Europe: Policies, Reforms and Achievements in EU Science and Innovation 2014-2019. Luxembourg: Publications Office of the European Union.

Fatur, P., and B. Likar. 2009. Ustvarjalnost zaposlenih za inovativnost podjetja: sistemski vidiki managementa idej kot gradnika uspešne organizacije. Koper: Fakulteta za management.

Heisig, P., O. A. Suraj, A. Kianto, C. Kemboi, G. P. Arrau, and N. F. Easa. 2016. 'Knowledge Management and Business Performance.' Journal of Knowledge Management 20 (6): 1169-98.

Henttonen, K., A. Kianto, and P. Ritala. 2016. 'Knowledge Sharing and Individual Work Performance: An Empirical Study of a Public Sector Organisation.' Journal of Knowledge Management 20 (4): 749-68.

Hsu, I. C. 2008. 'Knowledge Sharing Practices as a Facilitating Factor for Improving Organizational Performance through Human Capital: A Preliminary Test.' Expert Systems with Applications 35 (3): 1316-26.

Johnson, D., and F. Tilley. 1999. 'HEI and SME Linkages: Recommendations for the Future.' International Small Business Journal 17 (4): 66-81.

Krošelj, S. S. 2019. 'Subvencije P2 in uspešnost inovativnih podjetij. Master's thesis, Univerza na Primorskem.

Lee, P., N. Gillespie, L. Mann, and A. Wearing. 2010. 'Leadership and Trust: Their Effect on Knowledge Sharing and Team Performance.' Management Learning 41 (4): 437-81.

Lesjak, D. 2019. 'Measuring Impacts of Science and Research on the Society: Development, Issues and Solutions'. Management 14 (3): 219-36.

Ministrstvo za gospodarski razvoj in tehnologijo Republike Slovenije. 2019. 'Spodbujanje inovacij in tehnološkega razvoja.' http://mgrt.arhiv -spletisc.gov.si/si/delovna_podrocja/tehnoloski_razvoj/spodbujanje _inovacij_in_tehnoloskega_razvoja/

Muscio, A., and G. Vallanti. 2014. 'Perceived Obstacles to UniversityIndustry Collaboration: Results from a Qualitative Survey of Italian Academic Departments.' Industry and Innovation 21 (5): 410-29.

O’Kane, C., V. Mangematin, W. Geoghegan, and C. Fitzgerald. 2015. 'University Technology Transfer Offices: The Search for Identity to Build Legimacy.' Research Policy 44 (2): 421-37.

Organisation for Economic Co-Operation and Development. 2015. Frascati Manual 2015: Guidelines for Collecting and Reporting Data on Research and Experimental Development. Paris: Organisation for Economic Co-Operation and Development.

Pal, L. 2017. 'O pisarnah za prenos tehnologij na slovenskih J Ro.' In Pisarne za prenos tehnologij $v$ Sloveniji, edited by Š. Stres and L. Pal, 16-19. Ljubljana: Združenje profesionalcev za prenos tehnologij Slovenije.

Perkmann, M., Z. King, and S. Pavelin. 2011. 'Engaging Excellence? Effects 
of Faculty Quality on University Engagement with Industry.' Research Policy 40 (4): 539-52.

Pronk, J. T., S. Y. Lee., J. Lievense, J. Pierce, B. Palsson, M. Uhlen, and J. Nielsen. 2015. 'How to Set Up Collaborations between Academia and Industrial Biotech Companies.' Nature Biotechnology 33 (3): 237-40.

'Resolution on the Research and Innovation Strategy of Slovenia 20112020.' N.d. https://www.gov.si/assets/ministrstva/MIZS/Dokumenti/ Zakonodaja/EN/Resolution-on-Research-and-Innovation-Strategy -of-Slovenia_2011-2020.pdf

Robin, S., and T. Schubert. 2013. 'Cooperation with Public Research Institutions and Success in Innovation.' Research Policy 42 (1): 149-166.

Rodica, B., B. Vojnović, and D. Grujić. 2014. 'Raziskovanje inovacijske aktivnosti v slovenskih podjetjih.' Revija za ekonomske in poslovne vede 1 (1): 51-61.

Schwab, K., ed. 2019. The Global Competitiveness Report 2019: Insight Report. Geneva: World Economic Forum.

Stanovnik, P., and S. Uršič. 2019. 'Raziskovalno-razvojna vlaganja kot osnova za tehnološki razvoj v Sloveniji.' Journal of Innovative Business and Management 11 (1): 16-24.

Stare, M., M. Bučar, and B. Udovič. 2014. 'Soustvarjanje znanja med javnimi raziskovalnimi organizacijami in gospodarstvom za povečanje konkurenčnosti.' IB revija 48 (3-4): 53-59.

Statistični urad Republike Slovenije. 2020. 'Na voljo končni podatki o raziskovalno-razvojni dejavnosti (RRD) v 2018.' Statistični urad Republike Slovenije, 2 March. https://www.stat.si/StatWeb/News/Index/8692

Strašek, A., F. Pušavec, and B. Likar. 2020. 'Open Innovation and Business Performance Improvement in Strategic Business Alliances.' Management 25 (1): 133-44.

Tartari, V, and S. Breschi. 2012. 'Set Them Free: Scientists' Evaluations of the Benefits and Costs of University-Industry Research Collaboration.' Industrial and Corporate Change 21 (5): 1117-47.

Urad Republike Slovenije za makroekonomske analize in razvoj. 2019. Poročilo o razvoju 2019. Ljubljana: UMAR.

Vlada Republike Slovenije. 2019. 'Poročilo o uresničevanju Resolucije o raziskovalni in inovacijski strategiji Slovenije za obdobje 2015-2017.' Vlada Republike Slovenije, Ljubljana.

Zajc, M. D. 2012. Soustvarjanje in prenos znanja med malimi in srednjimi podjetji ter raziskovalnimi organizacijami. Ljubljana: Fakulteta za družbene vede.

'Zakon o raziskovalni in razvojni dejavnosti.' 2006. Uradni list Republike Slovenije, št. 61. https://www.uradni-list.si/1/objava.jsp?sop=2006-o12567. 